\title{
FOREWORD
}

\section{BY THE PRESIDENT}

\author{
SIR ALFRED WEBB-JOHNSON, BT., K.C.V.O., C.B.E., D.S.O., T.D. \\ Watchman, what of the night? \\ The Watchman said, The morning cometh, and also the night: \\ if ye will enquire, enquire ye: return, come. - Isaiah XXI, v.11 \& 12.
}

$\mathrm{T}$ he fateful night of May 10th - 11th 1941 saw the heaviest of the air attacks on London. It resulted in tremendous damage but the casualties inflicted on the Luftwaffe and the demonstration that London "could take it," led to a cessation of mass attacks by piloted aircraft, which up to that date had occurred nightly without intermission for over eight months. On that dreadful night many national buildings were destroyed, including the House of Commons, and that same night saw the destruction of a large part of the unique Museum of the Royal College of Surgeons.

The damage to the Museum was a disaster of the first order for it was a loss to science. The collections were so enormous that it had been impossible to arrange for their evacuation to the country, but many specimens had been moved to the basement and were saved. Some, however, had been placed in a deep reinforced tunnel well below the basement level of one part of the building. Unfortunately, this stronghold proved as illusory a defence as the Maginot Line, for it was under a part of the Museum which was completely laid waste; and, as the fallen buildings accumulated, a great mass of brickwork, made white hot by raging fires, turned the "safe deposit" into a kiln of superlative heat, and the specimens were destroyed.

The College was the headquarters of a Section of the National Fire Service but, as luck would have it, the Brigades had been called away to deal with extensive fires elsewhere before the College was hit. It is however unlikely that the firemen would have been able to achieve much, as parts of the Museum were turned into a fiery furnace; and the alcohol in which many of the old specimens were preserved added fuel to the flames.

The first attack was with incendiary bombs, but as the fire-watchers rushed to deal with these, high explosive bombs were dropped and a mighty holocaust resulted. Two of the Museum Halls were completely demolished. Another, which was a temple of pathology, was unroofed and the galleries destroyed. In this Hall was the National Memorial to John Hunter, which had been bricked in and covered with a thick roof of reinforced concrete. Over four years later, when the protective wall was removed, great was the relief to find that the statue had not suffered from the fires which had raged around it. The other two museum halls, which housed the anatomical specimens, were unroofed and the galleries damaged.

The specimens which had been saved were evacuated to the country and as soon as possible temporary roofs were erected over the three halls, the walls of which were still standing.

From the front façade a passer-by might think that the College had suffered but little. Fortunately, the damage to the administrative departments and research laboratories, although serious, was not disabling, and essential College work could be carried on. One bomb however had dropped through the roof of the Council Room into the Main Hall. This part of the building was unroofed, the floor of the council room destroyed and the main hall and staircase thrown open to the heavens. In addition the flames had been fanned by the wind into the upper part of the main block, and three floors of research laboratories were gutted. A temporary roof was built over the staircase and Council room, and the floor of that room and the ceiling of the hall were rebuilt.

The ceiling of the Library was rendered unsafe. Had not the books been moved to the country, owing to the foresight of Sir Hugh Lett, the damage from fire and water would have been disastrous. The library was originally designed by Barry - who built the Houses of Parliament - and was a perfect example of his best work. The ceiling was scheduled by "The Fine Arts Commission" as a work of art of national importance, and mouldings were taken of every detail. It was rebuilt exactly as it had been in design - but with a fortunate and unpremeditated result. The library is used for College dinners and other functions, and, before restoration, its acoustic properties were appalling. After rebuilding they were found to be perfect, the result presumably of different materials having been used in the reconstruction of the ceiling and the floor above.

Fortunately most of the essential temporary repairs were carried out before the V.1. bombs were launched on London. Had not the work been completed before this it would have been impossible to have had it done for some time, for the damage to buildings was terrific, and the needs of the people for houses in which to live or even exist were so urgent that all other building operations had to be abandoned. 
Soon after V.E. Day the laboratories were rebuilt and the library and administrative parts of the College put into full commission. The specimens were rehoused in the temporarily restored Museum Halls and recataloguing was proceeded with as rapidly as possible. The College is now ready to receive the specimens which have been promised from all parts of the world to fill the gaps in the collections.

In planning for the future, the Council have realised that their first duty is to restore the Museum, though not exactly as it was. The articulated skeletons of the larger mammals for example are now available for study at the Natural History Museum which did not exist in Hunter's time; while new developments in medical science demand places which were not provided before. But, in addition to this primary duty to restore the museum, the Council realise that greatly increased space is needed for research and for the instruction of post-graduate students of surgery and the surgical specialties. There is also an increasing demand for collegiate amenities such as common-rooms, dining and luncheon-rooms; and also for residential accommodation, particularly for graduates from the Dominions.

The Council have always been anxious to foster the closest possible relationships between the Royal College of Surgeons of England and the Sister Colleges in the Dominions. They therefore rejoice in the institution of a Commonwealth Travelling Professorship, which will provide for prominent teachers of medicine and surgery to make tours of the Commonwealth and Empire in order to take part in research and postgraduate education.

This long-desired development has been made possible by a generous gift from "a New Zealand family". The gift was anonymous in the first instance but the Council is now glad to have permission to disclose that the donor is Mr. Arthur Sims, a prominent New Zealand Industrialist, an ardent believer in the mission of the Commonwealth and Empire.

In order to restore the museum and make adequate provision for teaching and research, apart from providing residential quarters, the Council have been advised that $£ 250,000$ will be required over and above what may be recovered from the War Damage Commission. Towards this sum nearly $£ 180,000$ has been subscribed. The King headed the list of donors and contributions have been received from Queen Mary, the Princess Royal and the King of Egypt. Grants of £80,000 from the trustees of the Wellcome Foundation and $£ 20,000$ from the War Organisation of the British Red Cross Society and Order of St John of Jerusalem have been received. Substantial help was given promptly by sister colleges of surgeons, with a notable gift of over $£ 10,000$ from the fellows of the American College. The medical profession as a whole showed their sympathy through the British Medical Association.

Besides the evidence of the attachment and affection of the sister Surgical Colleges, the appeal launched in 1945 revealed the remarkable loyalty of the Fellows of the College where'er dispersed over the face of earth or water. Individual surgeons at home and in the Dominions and other countries, particularly Egypt, have subscribed most generously; and it has been an inspiring task to prepare plans for the future with so much loyal support. The help sent by surgeons living in the distant Dominions has been most striking, for they have but few opportunities of using the scientific facilities and social amenities which the College provides. Their support has convinced the Council that it is their duty to establish collegiate headquarters which surgeons and those aspiring to be surgeons can regard as their natural spiritual home.

Even with the present restricted space available efforts are being made to meet the requirements of post-graduate students. Besides arranging lectures and practical classes, a Common Room has been opened and luncheon is served in the College each day. Graduate students thus have opportunities of meeting socially the leading surgical teachers of the United Kingdom. College Dinners are held once a month, and graduate students are eligible to attend. It is impossible to overrate what it may mean to graduates at home and from overseas to have such opportunities of meeting the leading teachers of the country. What a precious memory it would have been for the writer if as a young graduate he had been able to dine or lunch or even stay at the Royal College of Surgeons and to have met the immortal Lister and others of the great men of his youthful days!

The Council have desired for some time that those practising special branches of surgery and the specialties allied to surgery should feel that the College provides for their academic requirements. Accommodation has therefore been provided for a Secretariat and meeting-rooms to serve the needs of the Faculties and Associations of various specialties; and representatives have been invited to attend the meetings of the Council. By Royal Charter, authority has now been given to co-opt additional Members of the Council to be representative of branches of practice not represented on the Council by the ordinary process of election; to arrange for special Final Examinations for the Fellowship of the College for those desiring to practise Ophthalmology and Otolaryngology; and to institute a higher diploma in Dental Surgery (F.D.S., R.C.S.). In addition, powers have been granted to establish such faculties in the College as may from time to time be thought fit.

A generous grant from the Bernhard Baron Trustees and the princely gifts of Sir William Collins enabled the Council to institute Professorships of Anatomy, Applied Physiology and Pathology. With these gifts and the great benefactions of the past from Sir Erasmus Wilson and Sir Buckston Browne, the endowment of the research departments has been built up to such an extent that the future scientific influence of the College is assured. Additional property has been acquired, and the College owns the freeholds of practically the whole of the South side of Lincoln's Inn Fields. Space is therefore available for the future development of the College of Surgeons and for other Colleges which may desire to occupy contiguous sites. 
In answer to the appeal, letters were received from all parts of the world asking for regular information about the College, and about recent events and forthcoming programmes. The Council have therefore felt it a duty to publish a monthly journal which will be known as "The Annals of the Royal College of Surgeons of England." In "The Annals" will be published a selection of Lectures delivered at the College, and the publication will also include items of historical interest, accounts of recent events, and a diary of forthcoming functions, lectures and practical classes.

It is hoped that "The Annals" will keep Fellows and Members of the College throughout the world conversant with recent advances in Surgery, with ex cathedra statements on various surgical subjects, and with the affairs of the College. Suggestions for the improvement of "The Annals" will be welcomed by the Editorial Committee of which Sir Cecil Wakeley is Chairman. 